\title{
Prevalence of Mastitis Pathogens in France: Antimicrobial Susceptibility of Staphylococcus aureus, Streptococcus uberis and Escherichia coli
}

\section{Bernard Poutrel ${ }^{1 *}$, Sylvain Bareille ${ }^{2}$, Guillaume Lequeux ${ }^{3}$ and Frédéric Leboeuf ${ }^{*}$}

1195 rue of the Mésangerie, Saint Cyr sur Loire 37540, France

${ }^{2}$ MSD Animal Health, 7 rue Olivier de Serres, Beaucouzé 49070, France

${ }^{3}$ ISAE 35, BioAgroPolis, 10 rue Claude Bourgelat, Javené, Fougères, 35133, France

\begin{abstract}
The prevalence of bovine mastitis in France was established using 11 publications covering the period 19952012. The papers involved epidemiological surveys or treatment trials. Bacteriological analyses were performed on 777,923 and 2341 aseptically collected quarter milk from acute, clinical and subclinical mastitis respectively. Escherichia coli and Streptococcus uberis were the most prevalent pathogens in acute and clinical mastitis whereas Staphylococcus aureus and coagulase negative staphylococci were the most frequently isolated pathogens in subclinical mastitis. The prevalence of Corynebacterium bovis and Streptococcus agalactiae was low whatever the severity of mastitis. The epidemiological data could be useful in the choice of treatment and provide indicators for future research with a view to developing new efficient vaccines. The susceptibility of 240 isolates ( 80 Streptococcus uberis, 80 Staphylococcus aureus, 80 Escherichia coli) isolated in 2013 from aseptically collected quarter milk from clinical and subclinical mastitis to 12 antimicrobial agents was determined by measuring their minimal inhibitory concentrations. Overall resistance levels were very low except for $S$. aureus towards penicillin G $(21.3 \%)$ and for Str. uberis towards tylosin and cloxacillin (respectively $13.8 \%$ and $32.5 \%$ ).
\end{abstract}

Keywords: Mastitis; Pathogens; Prevalence; Antimicrobial susceptibility; France

\section{Introduction}

Bovine mastitis is the most prevalent and most costly production disease in dairy herds. The economic impact includes cost for therapy, discarded milk, reduced milk production, culling and replacement. The most frequently isolated micro-organisms are Staphylococci, Streptococci and Coliforms, but other species may infect the udder. The panorama of udder pathogens varies between countries and also between subclinical and clinical mastitis. To our knowledge national surveys on microbial etiology of bovine mastitis have not been recently performed in France.

Antimicrobials are an important tool in mastitis control programs. Knowledge about antibiotic resistance trends is important to help the veterinarian in selecting the most appropriate antibiotic for treatment, because mastitis therapy is commonly initiated before bacterial susceptibility testing.

The aim of this study was to identify retrospectively the bacteria isolated from milk samples from French dairy herds and to determine the occurrence of antimicrobial resistance of major mastitis pathogens to commonly used antimicrobial agents.

\section{Material and Methods}

\section{Prevalence of pathogens}

The prevalence of mastitis pathogens was established using 11 publications covering the period 1995-2012 concerning epidemiological surveys [1-7] or treatment trials [8-11]. Quarter aseptic milk samples were collected according to the recommendations of the National Mastitis Council from cows in different farms, at different times if farms were repeatedly sampled, so that isolates could be considered epidemiologically independent [12]. Samples were submitted to different veterinary laboratories for identification of isolates. Bacteriological analyses were performed on 777, 923 and 2341 milk samples from cases of acute mastitis, clinical mastitis and subclinical mastitis respectively.
Acute mastitis involved both local (inflammation, modification of the milk....) and systemic (fever, loss of appetite, drop of the milk production ...) clinical signs. Clinical mastitis was defined by the presence of local signs and subclinical mastitis by the absence of local and systemic signs and somatic cell count higher than $200.000 / \mathrm{ml}$.

\section{Antimicrobial susceptibility testing}

The susceptibility to 12 antimicrobials agents of 240 isolates, 80 Staphylococcus aureus, (S. aureus), 80 Streptococcus uberis (Str. uberis), 80 Escherichia coli (E. coli) from aseptic quarter milk samples from cows with clinical or subclinical mastitis was determined. Milk samples were collected in 2013 from different regions in France, in different farms and on different cows and were considered epidemiologically independent. Isolates were identified by standardized methods [12] Minimal inhibitory concentration (MIC) was determined using the broth microdilution method according to the recommendations of the Clinical and Laboratory Standards Institute [13]. Strains ATCC 29212 Enterococcus faecalis), 29213 (Staphylococcus aureus), and 27853 (Pseudomonas aeruginosa) were used as quality control on each day of testing. Breakpoints were defined according to Clinical and Laboratory Standards Institute [14] or European Committee on Antimicrobial Susceptibility Testing guidelines [15] when available.

\section{Results and Discussion}

Although there is a scientific limitation to a country wide survey

*Corresponding author: Bernard Poutrel, 95 rue of the Mésangerie, Saint Cyr sur Loire 37540, France, Tel: +33247547897; E-mail: b.poutrel@wanadoo.fr

Received March 02, 2018; Accepted March 03, 2018; Published March 15, 2018

Citation: Poutrel B, Bareille S, Lequeux G, Leboeuf F (2018) Prevalence of Mastitis Pathogens in France: Antimicrobial Susceptibility of Staphylococcus aureus, Streptococcus uberis and Escherichia coli. J Vet Sci Technol 9: 522. doi: 10.4172/2157-7579.1000522

Copyright: (c) 2018 Poutrel B, et al. This is an open-access article distributed unde the terms of the Creative Commons Attribution License, which permits unrestricted use, distribution, and reproduction in any medium, provided the original author and source are credited. 
Citation: Poutrel B, Bareille S, Lequeux G, Leboeuf F (2018) Prevalence of Mastitis Pathogens in France: Antimicrobial Susceptibility of Staphylococcus aureus, Streptococcus uberis and Escherichia coli. J Vet Sci Technol 9: 522. doi: 10.4172/2157-7579.1000522

Page 2 of 3

such as the variation in herd size, management skills, parity, milk yield and other parameters, the size of this data base (4041 quarter milk samples) helps to give a fair indication of general etiology of udder infections in France according to the severity of the mastitis.

Concerning acute mastitis, E. coli was the most frequently isolated bacteria in milk samples followed by Str. uberis (Table 1). S. aureus was rarely involved and Streptococcus. agalactiae (Str. agalactiae) not found. The order of prevalence was reversed for clinical mastitis, Str. uberis was in the first position followed by E. coli and coagulase negative staphylococci (CNS) (Table 2). The majority of the subclinical mastitis was caused by gram positive pathogens, S. aureus and CNS (Table 3). Unexpectedly a high prevalence of CNS (57.5\%) and Corynebacterium bovis (C. bovis) (28\%) was reported one article [10]. Whatever the severity of mastitis considered C. bovis and Str. agalactiae were uncommon in this study. These results are probably related to the efficacy of the control methods of mastitis and good susceptibility to antibiotic of these bacterial species.

The pattern of major pathogens causing organisms as determined from culture of milk samples has changed significantly over the last 40 years with a substantial increase in the percentage of CNS and Str. uberis, a virtual eradication of Str. agalactiae and the disappearance of Mycoplasma. All Str. uberis isolates were susceptible to the $\beta$ lactamins with the exception of cloxacillin for which 26 isolates (32.5\%) were resistant (Table 4). Susceptibility to gentamicin and tylosin was relatively low.

Concerning S. aureus resistance was found for the penicillin G (17 isolates-21.3\%) cephalexin (2 isolates-2.5\%) and cefquinome (2 isolates-2.5\%) (Table 5). The level of resistance for penicillin was lower than level previously reported in France (36.2\%) between 19982000 [16]. For reason of natural resistance, 4 antibiotics tested for Str. uberis and $S$. aureus were not evaluated with E. coli (Table 6). Except for cephalexin for which $\mathrm{MCI}_{90}$ is high, E. coli isolates were relatively susceptible to all antibiotics tested. Only 2, 2 and 7 isolates were resistant to the enrofloxacin, association amoxicillin-clavulanic acid, and cefapirin respectively.

The choice of the antimicrobial treatment of mastitis cannot be only based on the MIC values because high values are not closely related with bacteriological cure in vivo. Other parameters such as the distribution and persistence of the antibiotic in the udder depend on of

\begin{tabular}{|c|c|}
\hline Pathogens (N=777) & Range of prevalence (\%) \\
\hline Isolates Gram + & $\mathbf{2 9 . 9 - 4 7}$ \\
\hline Staphylococcus aureus & $4.3-7.4$ \\
\hline Coagulase negative Staphylococci & $0.9-5.8$ \\
\hline Corynebacterium bovis & $0-1.1$ \\
\hline Steptococcus uberis & $10.6-26$ \\
\hline Steptococcus dysgalactiae & $1.1-7.2$ \\
\hline Streptococcus agalactiae & 0 \\
\hline Streptococcus sp. & 0 \\
\hline Enterococcus sp. & $0-5.3$ \\
\hline Arcanobacterium pyogenes & $0-3.2$ \\
\hline Other & $0-1.1$ \\
\hline Isolates Gram- & $\mathbf{4 9 . 1 - 6 9 . 6}$ \\
\hline Escherichia coli & $47.2-64.9$ \\
\hline Klebsiella sp. & $0-4.3$ \\
\hline Pseudomonas $s p$. & $0-2.1$ \\
\hline Pasteurella sp. & $0-2.6$ \\
\hline Yeast & $0.4-1.6$ \\
\hline
\end{tabular}

Table 1: Acute Mastitis: Prevalence of the different pathogens [6-9]. the pharmacological properties of the product and must be considered. However high MIC values are generally associated with treatment failure. Overall more than $50 \%$ of all clinical and subclinical mastitis were caused by gram positive pathogens and acute mastitis by gram negative pathogens. These data may help the veterinarian for the choice

\begin{tabular}{|c|c|}
\hline Pathogens (N=923) & Range of prevalence (\%) \\
\hline Isolates Gram + & $\mathbf{5 7 - 7 8}$ \\
\hline Staphylococcus aureus & $7-18.9$ \\
\hline Coagulase negative Staphylococci & $6-15.8$ \\
\hline Corynebacterium bovis & $0-5$ \\
\hline Steptococcus uberis & $18-37$ \\
\hline Steptococcus dysgalactiae & $03-10$ \\
\hline Streptococcus agalactiae & $0-3.2$ \\
\hline Streptococcus sp. & $0-6$ \\
\hline Enterococcus sp. & $0-6.8$ \\
\hline Other & $0-7.7$ \\
\hline Isolates Gram- & $\mathbf{2 3 - 3 3}$ \\
\hline Escherichia coli & $16.7-24$ \\
\hline Klebsiella sp. & $0-6$ \\
\hline Pseudomonas sp. & $0-3$ \\
\hline Other & $0-6.3$ \\
\hline No identified & $0-22$ \\
\hline Yeast & $1.8-6$ \\
\hline
\end{tabular}

Table 2: Clinical Mastitis: Prevalence of the different pathogens [2-4,11].

\begin{tabular}{|c|c|}
\hline Pathogens (N=2341) & Range of prevalence (\%) \\
\hline Isolates Gram + & $\mathbf{6 5 - 9 8 . 9}$ \\
\hline Staphylococcus aureus & $6.2-41$ \\
\hline Coagulase negative Staphylococci & $9-57.5$ \\
\hline Corynebacterium bovis & $0-28$ \\
\hline Steptococcus uberis & $5.6-23.5$ \\
\hline Steptococcus dysgalactiae & $0-8$ \\
\hline Streptococcus agalactiae & $0-1$ \\
\hline Streptococcus sp. & $0-4$ \\
\hline Enterococcus sp. & $0-6.7$ \\
\hline Isolates Gram- & $\mathbf{0 - 1 5 . 7}$ \\
\hline Escherichia coli & $0-15$ \\
\hline Klebsiella sp. & $0-6$ \\
\hline Pseudomonas $s p$. & $0-3$ \\
\hline Other & $0-11.2$ \\
\hline No identified & $1-22$ \\
\hline
\end{tabular}

Table 3: Subclinical Mastitis: Prevalence of the different pathogens [1-3,5,10].

\begin{tabular}{|c|c|c|c|c|}
\hline \multirow{2}{*}{ Antibiotic } & \multirow{2}{*}{ Resistance (\%) } & \multicolumn{3}{|c|}{ MIC $(\mathbf{\mu g} / \mathbf{m l})$} \\
\cline { 3 - 5 } & & Breakpoints & MIC $_{50}$ & MIC $_{90}$ \\
\hline Cephalonium & Not available & Not available & 0.03 & 0.06 \\
\hline Cefapirin & 0 & $\geq 16$ & 0.03 & 0.25 \\
\hline Cefquinome & 0 & $\geq 4$ & 0.03 & 0.25 \\
\hline Amoxicillin & 0 & $\geq 16$ & 0.06 & 0.25 \\
\hline Clavulanic acid & 0 & $\geq 16$ & 0.25 & 0.25 \\
\hline Cefalexin & 0 & $\geq 4$ & 0.125 & 0.5 \\
\hline Nafcillin & 0 & $\geq 4$ & 0.125 & 0.5 \\
\hline Cefazolin & 0 & $\geq 4$ & 0.03 & 1 \\
\hline Penicillin G & 0 & $>2$ & 0.5 & 1 \\
\hline Enrofloxacin & 0 & $\geq 4$ & 0.25 & 4 \\
\hline Cloxacillin & 32.5 & $\geq 8$ & 8 & 32 \\
\hline Gentamicin & 67.5 & $\geq 4$ & 1 & $>256$ \\
\hline Tylosin & 13.75 & & & \\
\hline
\end{tabular}

Table 4: Resistance and Minimal Inhibitory Concentrations for Streptococcus uberis isolates $(\mathrm{N}=80)$. 
Citation: Poutrel B, Bareille S, Lequeux G, Leboeuf F (2018) Prevalence of Mastitis Pathogens in France: Antimicrobial Susceptibility of Staphylococcus aureus, Streptococcus uberis and Escherichia coli. J Vet Sci Technol 9: 522. doi: 10.4172/2157-7579.1000522

\begin{tabular}{|c|c|c|c|c|}
\hline \multirow{2}{*}{ Antibiotic } & \multirow{2}{*}{ Resistance (\%) } & \multicolumn{3}{|c|}{ MIC $(\boldsymbol{\mu g} / \mathbf{m l})$} \\
\cline { 3 - 5 } & & Break points & $\mathbf{M I C}_{\mathbf{5 0}}$ & MIC $_{90}$ \\
\hline Cephalonium & Not available & Not available & $\leq 0.06$ & 0.125 \\
\hline Cefapirin & 0 & $\geq 32$ & $\leq 0.125$ & 0.25 \\
\hline Cefquinome & 2.5 & $\geq 4$ & 0.25 & 0.5 \\
\hline Amoxicillin & 0 & $\geq 8$ & 0.125 & 0.5 \\
\cline { 1 - 3 } Clavulanic acid & 0 & $\geq 8$ & 2 & 4 \\
\hline Cefalexin & 2.5 & 4 & 0.25 & 0.5 \\
\hline Nafcillin & 0 & $\geq 4$ & 0.25 & 0.5 \\
\hline Cefazolin & 0 & $\geq 0.25$ & $\leq 0.06$ & 0.5 \\
\hline Penicillin G & 21.25 & $>2$ & 0.125 & 0.25 \\
\hline Enrofloxacin & 1.25 & $\geq 4$ & 0.25 & 0.25 \\
\hline Cloxacillin & 0 & $\geq 8$ & $\leq 0.25$ & $\leq 0.25$ \\
\hline Gentamicin & 0 & $\geq 4$ & 1 & 2 \\
\hline Tylosin & 2.5 & & & \\
\hline
\end{tabular}

Table 5: Resistance and Minimal Inhibitory Concentrations for Staphylococcus aureus isolates $(\mathrm{N}=80)$.

\begin{tabular}{|c|c|c|c|c|}
\hline \multirow{2}{*}{ Antibiotic } & \multirow{2}{*}{ Resistance (\%) } & \multicolumn{3}{|c|}{ MIC $(\boldsymbol{\mu g} / \mathbf{m l})$} \\
\cline { 2 - 5 } & Not available & Not available & 2 & 4 \\
\hline Cephalonium & 1.25 & $\geq 32$ & 4 & 8 \\
\hline Cefapirin & 0 & $\geq 8$ & 0.06 & 0.06 \\
\hline Amoxinome & 2.5 & $>16$ & 1 & 8 \\
\hline Clavulanic acid & 0 & $>16$ & 8 & 16 \\
\hline Cefalexin & 0 & $>4$ & 1 & 1 \\
\hline Cefazolin & 2.5 & $>4$ & 0.03 & 0.03 \\
\hline Enrofloxacin & 1.25 & $>4$ & $\leq 0.25$ & 0.5 \\
\hline Gentamicin & & MIC $_{50}$ & \\
\hline
\end{tabular}

Table 6: Resistance and Minimal Inhibitory Concentrations for Escherichia coll isolates $(\mathrm{N}=80)$.

of the treatment when mastitis therapy is initiated before bacterial susceptibility testing. Presently recommendations exist for a limited use of antibiotics in order to prevent the increase of resistance both for animal and human isolates. This consideration underlines the need for efficient vaccines to prevent intramammary infections especially those caused by S. aureus and Str. uberis.

\section{Acknowledgements}

The authors would like to thank Pascal Rainard for the critical reading of the manuscript.

\section{References}

1. Bidaud $O$, Houffschmitt $P$, Viguerie $Y$ (2007) Aetiology of cattle mastitis in France between 2005 and 2007. Proceedings of Bovine Nantes Day, Nantes,

pp: 121-122.

2. Botrel AM, Haenni M, Morignat E, Sulpice P, Madec JY, et al. (2010) Distribution and antimicrobial resistance of clinical and subclinical mastitis pathogens in dairy cows in Rhône-Alpes, France. Foodborne Pathog Dis 7: 479-487.

3. Fabre JM, Morvan H, Lebreux B (1997) Estimation of the frequency of the germs responsible for mastitis in the dairy cow in France. Renc Rech Ruminants 4: 283.

4. Fabre JM, Morvan H, Lebreux B (1997) Estimation of the frequency of germs responsible for mastitis in France. Part 2 Sub clinical Mastitis. Bulletin Groupements Techniques Vétérinaires 5: 9-15

5. Laumonnier G, Auvigne V, Bonnier M (2010) Etiologic Investigation of Dairy Cow Acute Mastitis: Relationships between Breast Infection and Sepsis. Proceedings Days National Society of Veterinary Technical Groupings, Lille, pp: 1091-1100.

6. Laumonnier G, Leboeuf F (2012) Etiology, clinical and prognosis of severe mastitis: results of a study conducted in 17 veterinary practices in the Greater West. Proceedings Journées National Society of Veterinary Technical Groups, p: 1059

7. Poutrel B, Fromageau A (2008) Estimation of the prevalence of pathogens involved in acute clinical mastitis. Bulletin Groupements Techniques Vétérinaires 43: 65-68.

8. Abric JL, Serieys $F$ (2001) Lactating treatment of subclinical mastitis in dairy cows. Efficacy of cloxacillin-gentamicin combination and complementary treatment with NSAID. Bulletin Groupements Techniques Vétérinaires 12: 5964.

9. Grandemange E, Fournel S, Giboin H, Woehrle F (2012) Efficacy and safety of a single injection of marbofloxacin in the treatment of bovine $E$. coli mastitis in lactating dairy cows. Revue Méd Vét 168: 10-12, 219-228.

10. Robert A, Bareille N, Roussel P, Poutrel B, Heuchel V, et al. (2006) Interdependence of udder quarters for new intramammary infection during the dry period in cows submitted to selective antibiotic therapy. J Dairy Sci 73 : 345-352.

11. Serieys F, Raguet Y, Goby L, Schmidt H, Friton G (2005) Comparative efficacy of local and systemic antibiotic treatment in lactating cows with clinical mastitis. J Dairy Sci 88: 93-99.

12. Hogan JS, Gonzalez RN, Harmon RJ, Nickerson SC, Oliver SP, et al. (1999) Laboratory handbook on bovine mastitis. Revised edition, National Mastitis Council Inc., Madison, Wisconsin, USA.

13. Clinical and Laboratory Standards Institute (2015) VETO-A4 Performance standards for antimicrobial susceptibility testing. Wayne, Pennsylvania, USA.

14. Clinical and Laboratory Standards Institute (2013) VET01-S3 Performance standards for antimicrobial disk and dilution susceptibility tests for bacteria isolated from animals. Wayne, Pennsylvania, USA.

15. European Committee on Antimicrobial Susceptibility Testing (2017) October 2017. Available from: http://www.eucast.org/

16. Faublée VG, Carret $G$, Houffschmitt $P$ (2003) In vitro activity of 10 antimicrobial agents against bacteria isolated from cows with clinical mastitis. Vet Rec 152 466-470. 